\title{
Decolorization Study of Reactive Red-11 by using Dye Degrading Bacterial Strain Lysinibacillus boronitolerans CMGS-2
}

\author{
Madhuri R. Basutkar and Channappa T. Shivannavar* \\ Department of Microbiology, Gulbarga University, Kalaburagi-585106 \\ *Corresponding author
}

\begin{tabular}{l} 
Ke y w or d s \\
Thermophillic, \\
$\begin{array}{l}\text { Reactive red-11 } \\
\text { (RR-11), IMTECH, } \\
\text { MTCC }\end{array}$ \\
\hline Article Info \\
$\begin{array}{l}\text { Accepted: } \\
10 \text { May } 2019 \\
\text { Available Online: } \\
\text { 10 June } 2019\end{array}$ \\
\hline
\end{tabular}

\section{Introduction}

Nature itself colorful and synthetic dyes are available in two forms natural and manmade synthetic dyes. Nowadays various chemically synthesized dyes which became essential part of life (Manohar et al., 2001). Synthetic dyes creating a lot of problems to nature. Dyes are being widely used in many industries, especially the textile industries. These industries release, untreated dye contaminated water in to the environment, which leads complications on the earth and water bodies. One of the survey raveled textiles industries are the major source of polluters of India (Kumar et al., 2012). These industries are greatest generators of liquid, it is estimated that daily nearly 280000 tons of contaminated dyes released in water.

In Textile industries $93 \%$ of the outgoing water comes out as colored wastewater and also contains high concentration of organic compounds and heavy metals (Gupta et al., 2014). Strict Legislations has to be made to control especially azo based dyes. These azo dyes widely used in the industries majorly reactive azo dyes are largest synthetic dyes 
constituting $60-70 \%$ of all organic colorants (Saratale et al., 2013). In a waste water dye concentration may ranges from $5-1500 \mathrm{mg} / \mathrm{L}$ (Jadhav et al., 2010). Due to heavy discharge of synthetic dyes leads accumulation, which effects on aquatic life, and humans, and presence of aromatic compounds, makes dyes to xenobiotic, carcinogenic and mutagenic (Lu et al., 2010). Structurally these dyes contains $\mathrm{N}=\mathrm{N}$ bonds, attached to a benzene ring, various other compounds like $\mathrm{SO}_{3} \mathrm{H}$, $\mathrm{SO}_{2} \mathrm{NH}_{2}$, attached to a aromatic nucleus which makes into recalcitrant (Jain et al., 2012). Even a little amount of dye discharges in water leads ecological instability to aqualives, reduction in photosynthesis, toxicity level increases, alternations BOD, COD, TOC,PH, ranges etc (Lade et al.,2012).

Various microorganisms like fungi, actinomycetes, bacteria are used, out of all bacteria are used widely. Bacterial degradation is fastest compare to fungal decolarisation (Tapia and Tusell, 2011). Bacteria having ability to degrade dye in a single or mixed cultures (Chang et al., 2010). Presently work carried out to achieve effective decolorisation, Lysinibacillus boronitolarans CMGS-2 given excellent results in the decolorisation RR-11.

\section{Materials and Methods}

Source of sample-samples brought from in and surroundings of dying industries, soil samples, dye contaminated soil, industrial discharged water sample were collected from solapur, Maharashtra.

\section{Dyes and chemicals}

A total of six dyes were used in this study, Purchased from sigma aldirich (U.S.A), Heena and Colorise dying industries (Gujarat, India). They were Reactive blue 4, Reactive yellow 86, Reactive navy blue 59, Reactive orange 16, and Reactive violet 1. and Reactive red 11. Out of these dyes, isolate shown good decolorisation in reactive red 11(RR-11) and it is carried further for the further experiments. For the preparation synthetic media and broth, HI-media, SD-fine chemicals were used.

Synthetic mineral salt medium for the decolorisation experiments (Brilon et al., 1981) with little modifications

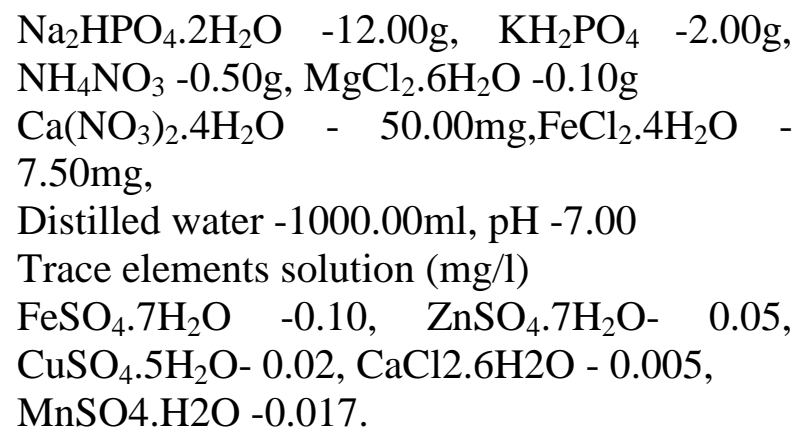

\section{Preparation of stock solution}

Isolation, screening, and identification, biochemical tests for dye degrading bacteria:Ten grams of soil sample and $10 \mathrm{ml}$ of water effluents were added in $100 \mathrm{ml}$ of normal saline $(0.9 \%)$ in $250 \mathrm{ml}$ conical flasks and kept on rotary shaker at $150 \mathrm{rpm}$ for 1 hour and stopped it left for the settling of soil. After settling $10 \mathrm{ml}$ of supernatant was used for the inoculating the MSM broth containing 50 ppm Reactive red -11 dye as sole of carbon and incubated at $35^{0} \mathrm{C}$ and kept for observations more than $50 \%$ decolorised flasks were selected visually observed daily till there is complete or more than $50 \%$ change in the visual color. The degradation was confirmed by UV-vis spectrophotometer Optical density checked at 540nm. Maximum degradation showing flasks were selected, further processed for isolation purpose, loopful of decolrised sample streaked on the, MSM agar medium containing reactive red 11 dye. Microbial colonies showing clear 
zone, were picked up and again cultured on the NA agar plate and observed for the colony characteristics and performed the gram staining motility. Different types of colonies were selected and subculture on MSM agar slants.

\section{Decolorization process}

Isolates grown in $10 \mathrm{ml}$ nutrient broth and incubated for 24hours of duration and transferred it to a $100 \mathrm{ml}$ MSM medium containing $50 \mathrm{ppm}$ of dye and incubated at 35

${ }^{0} \mathrm{C}$ maximum decolorized flasks were selected and isolated the bacterial strains pure culture of dye degrading bacterial strains were selected and sub cultured on Nutrient Agar slants. Potential isolates were preserved at 4.c in $30 \%$ glycerol and further used for biochemical property analysis (holt et al., 1994).

\section{Decolorisation assay}

For investigating the RR-11 degradation, isolated bacterial cultures used. For the decolorization $10 \%$ of bacterial inoculums were added to the $100 \mathrm{ml}$ of MSM broth with $50 \mathrm{ppm}$ of RR-11 dye (Decolorization medium). The decolorization medium without culture served as control. The flasks were incubated at $35{ }^{0} \mathrm{C}$. Every 4 hour $1 \mathrm{ml}$ of the sample was drawn from each flask and analyzed for the dye concentration broth taken in the $2 \mathrm{ml}$ centrifuged tubes centrifuged at $10000 \mathrm{rpm}$ for the 10mins, supernatant of culture drawn and optical density checked at $540 \mathrm{~nm}$ by using in a UV - Vis spectrophotometer. A decrease in the optical density with incubation time period is taken as an indicator of decolorization. To confirm the decolorization is due to degradation of dye not due to change in the $\mathrm{pH}$ of the medium and adsorption or absorption by change in the $\mathrm{pH}$ of the culture filtrate with addition $\mathrm{HCl}$ or $\mathrm{NaOH}$. The adsorption was tested by dissolving the culture pellet in the solvent.
Similarly absorption was performing by analyzing the dye in the cell lysates. The percentage of degradation was calculated.by using formula. Calculation of \% decolorization:- \% Decolorization = Initial absorbance-Observed absorbance/Initial absorbance x 100. Maximum degradation shown isolate selected for the identification.

\section{Results and Discussion}

\section{Optimization study of RR-11 decolorisation by isolate CMGS -2}

\section{Effect of $\mathrm{pH}$ on the decolorisation of Reactive Red-11}

For effective degradation $\mathrm{pH}$ is an important factor. Experiment carried out different $\mathrm{pH}$ ranges from 4to 14, isolate CMGS-2 shown an excellent degradation in alkaline condition. At $\mathrm{pH} 8,-96 \%$ and $\mathrm{pH}-8$ is optimum for our isolate and with other $\mathrm{pH}$ at 9-it was $95.9 \%$, in at $\mathrm{pH}-10$ it was showed 95.8 maximum decolorisation, it reveals isolate CMGS-2 uses alkaline $\mathrm{pH}$ for the better decolorisation. For industrial usage alkaline condition is optimum, to maintain neutral $\mathrm{pH}$ needs lots of efforts. Various reports shown on degradation in the alkaline $\mathrm{pH}$ range. (Bhatt et al., 2012) shown bacterial consortia SpNb1, shown degradation in the range from $6-9 \mathrm{pH}$. at $\mathrm{pH}$ 7.5 with maximum dye decolorization $94.95 \pm$ 0.09 observed. Shiwanella sps IFN4 shown degradation in mixed azo dyes $\mathrm{pH}$ ranging from 5-9(Imran et al., 2014).

\section{Effect of temperature on the decolorisation Of Reactive Red-11}

Decolorisation study carried out in different temperature ranges, from $20^{\circ} \mathrm{C}$ to $50{ }^{\circ} \mathrm{C}$. Isolate CMGS-2 shown maximum decolorisation $40^{\circ} \mathrm{C} 96.06 \%$. At $45^{\circ}$ it was 96.23\%. At $-50^{\circ} \mathrm{C}-95.6 \%$ even it showed decolorisation in $20^{\circ} \mathrm{C}-66.78 \%$ in 12 hours of duration. From these it reveals that isolate 
degrades dye in range of temperature. Decolorization of Acid Orange dye by Staphylococcus hominis RMLRT03 strain was found to be $35^{\circ} \mathrm{C}$ with $92.38 \%$ decolorization (Singh et al., 2014).

The decolorization of RB-172 by Shewanella haliotis DW01 was found to be significant at $30{ }^{\circ} \mathrm{C}$ and $35{ }^{\circ} \mathrm{C}$ with maximum decolorization $78 \%$ at $35^{0 \mathrm{C}}$ in $12 \mathrm{~h}$ (Radhika et al., 2014).

\section{Effect of salt on the degradation of} Reactive Red-11

Reactive dye contain high amount of sodium salts. To check the salt tolerance of our isolate salt concentration is ranging from $1 \%$ to $5 \%$. For $1 \%$ - it showed $95.4 \%$, At $5 \%$ - it was $86 \%$. The concentration of salt increases the decolorisation capacity shown decreasing order.

It reveals that the high concentration of salt decreases the decolorisation. (De Baere et al., 1987) demonstrated that increase in the sodium concentration degradation rate decreases. Panswad et al., I1999) revealed that these may due plamolysis causes, which make decolorisation slower. (Bheemaraddi et al., 2014) reported Paracoccus sps shown decolorisation up to $6 \%$ salt concentration.

\section{Effect of inoculum on the degradation of Reactive Red-11}

Inoculum concentration helps in the better decolorization of dye, isolate CMGS-2. 95.5\%. as per (Sharma et al., 2015) $5 \mathrm{ml}$ inoculums size was the optimum for the decolorization (Sahastrabuhe et al., 2014) revealed Enterococcus faecalis YZ66 shown $10 \%$ of inoculums size as optimum. Bheemaraddi et al., (2014) studied 5 to $20 \%$ of inoculums size for the decolorisation and decolourization activity of Paracoccus has shown high in $20 \%$ of inoculums size.
Effect of dye on the Decolorisation of Reactive Red-11

Decolorisation capacity of CMGS-2 was checked with the increasing concentration of dye for the duration of 12 hours of duration, dye concentration was checked from 100ppm to $1000 \mathrm{ppm}$. Optimum dye concentration was $200 \mathrm{mg} /$-it was $98 \%$, and at $400 \mathrm{ppm}$ it was $98.1 \%$, was optimum for the better degradation and further experiment carried out by the same concentration of the dye. Further at, for 1000ppm isolate was showing $43 \%$ decolorisation. The results CMGS-2 was higher compare to other reports, Enterocooccus fecalis YZ66 shown decolorisation up to 700rpm (Sahastrabudhe et al., 2014). The decolorization of textile dye reactive golden yellow 84 by the isolated bacterium Rhizobium sp. F5 showed upto $300 \mathrm{mg} / \mathrm{L}$ decolorisation within 24 hours of duration (Narsinge et al., 2013). Various Reports Showed increase the capacity of dye there were decrease in the degradation that may be due to reactive azo dye inhibits nucleic acid synthesis in microbial cell growth (Kalyani et al., 2009).

\section{Effect of Static and Shaking Conditions on the decolorisation of Reactive Red-11}

To study the effect of aeration on the degradation of reactive red -11 , flasks were kept on shaker at $180 \mathrm{rpm}$. For 12 hour of duration. Isolate CMGS-2 shown better decolorisation in the static condition. (sahasrabudhe et al., 2014) Showed static condition only favorable for the decolorisation.

Optimization of additional nutrients for maximum decolorization of isolate CMGS

Effect of corbon and nitrogen sources on the decolorization of Reactive Red-11

Different carbon sources were taken to 
increase the efficiency of decolorisation, but isolate shown no significant increase in the decolorisation of RR-11 dye, in glucose $1 \mathrm{gm} / \mathrm{L}$ It Showed $90.5 \%$. Sucrose it was $84.3 \%$, starch $73.4 \%$ reveals isolate CMGS-2 used only dye as a carbon soul source of energy, in other reports showed, Oturkar et al., (2010) showed additional carbon sources is essential for increase in dye degradation efficiency of Bacillus lentu B1377. (Shah et al., 2014) studied Pseudomonas spp showed moderate decolorization in the presence of sucrose $(50 \%)$ lactose $(45 \%)$ and starch $(55 \%)$ and decolorization in the presence of glucose was reported (62\%).

\section{Effect of nitrogen sources on the degradation Of Reactive Red-11}

Various nitrogen sources are used, to check the efficiency of isolate CMGS-2.in yeast extract it shown $97.4 \%$, beef extract it shown $93.2 \%$, peptone it was $88.1 \%$, potassium nitrate it shown $71.5 \%$. Ammonium nitrate shown degradation $70.1 \%$, and these study results yeast extract was the excellent substrate for the better degradation. Similarly Pseudomonas aeruginosa GSM3 showed complete decolorization of Reactive Violet 5 within $16 \mathrm{~h}$ in the presence of yeast extract (Bheemaraddi et al., 2014).

\section{Effect of yeast extract on the degradation Of Reactive Red-11}

Out of all nitrogen sources yeast extract played a main role in the degradation of reactive dyes. For the optimization of $0.5 \%$, $1.0 \%, 1.5 \%, 2.0 \%$, yeast extract was taken. CMGS-2 showed Optimum degradation in $0.1 \%$ of yeast extract.

Fig.1 Optimization of $\mathrm{pH}$ on the decolorisation of Reactive Red-11

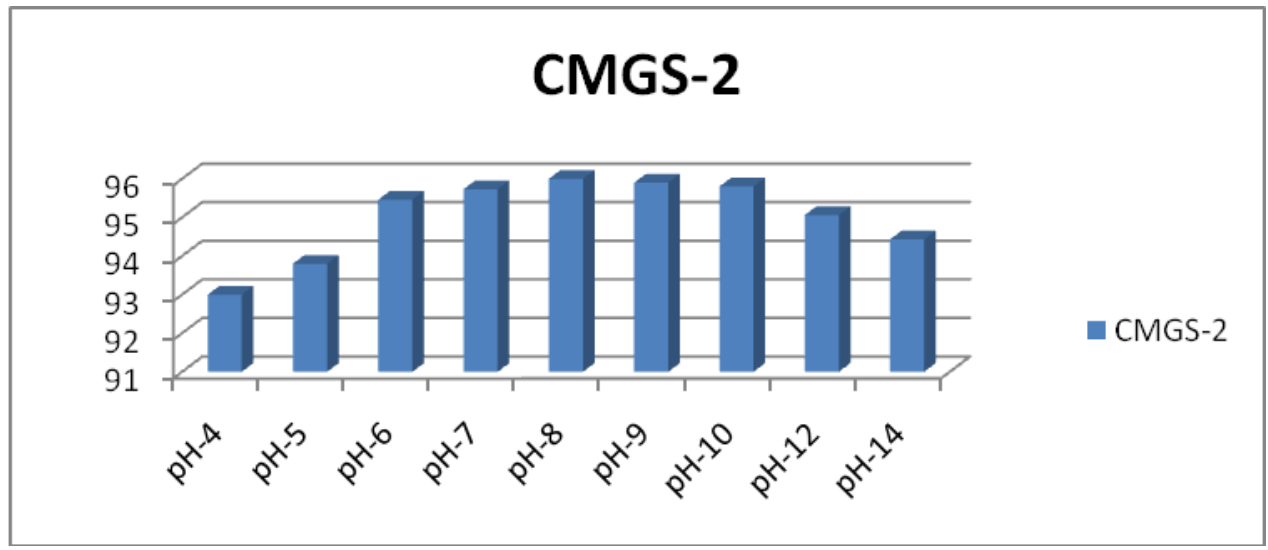

Fig.2 Optimization of temperature on the decolorisation of Reactive Red-11

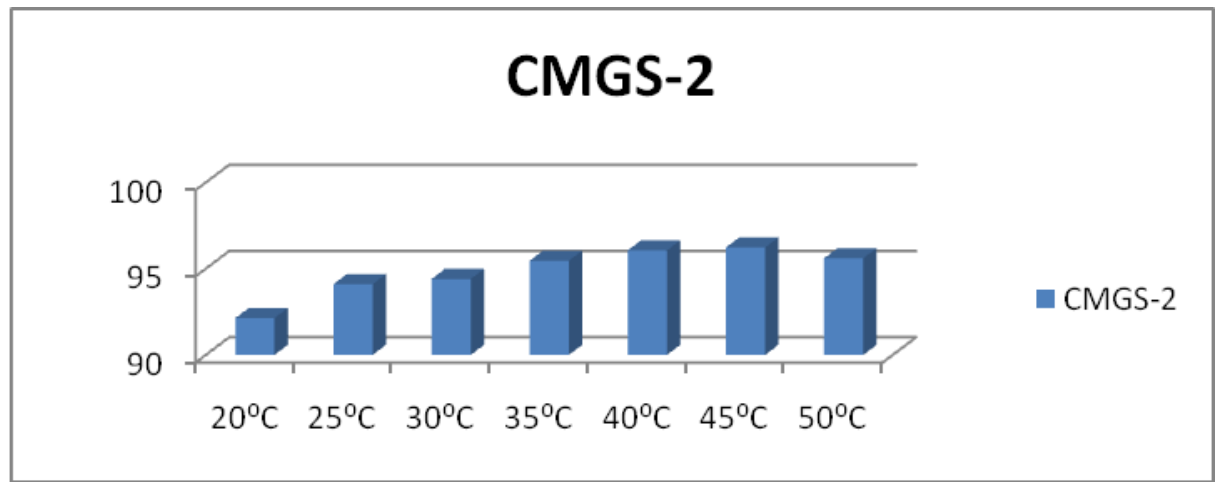


Fig.3 Effect of salt concentration on the decolorisation of Reactive Red-11

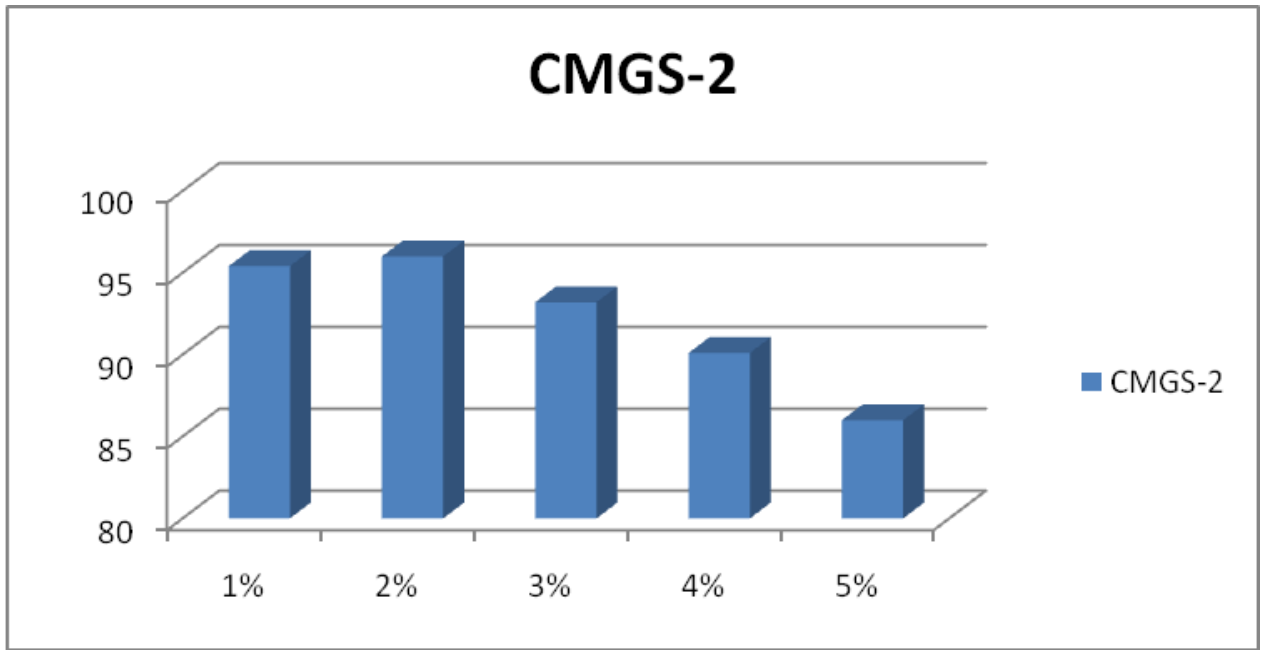

Fig.4 Optimization of inoculum concentration on the decolorisation of Reactive Red-11

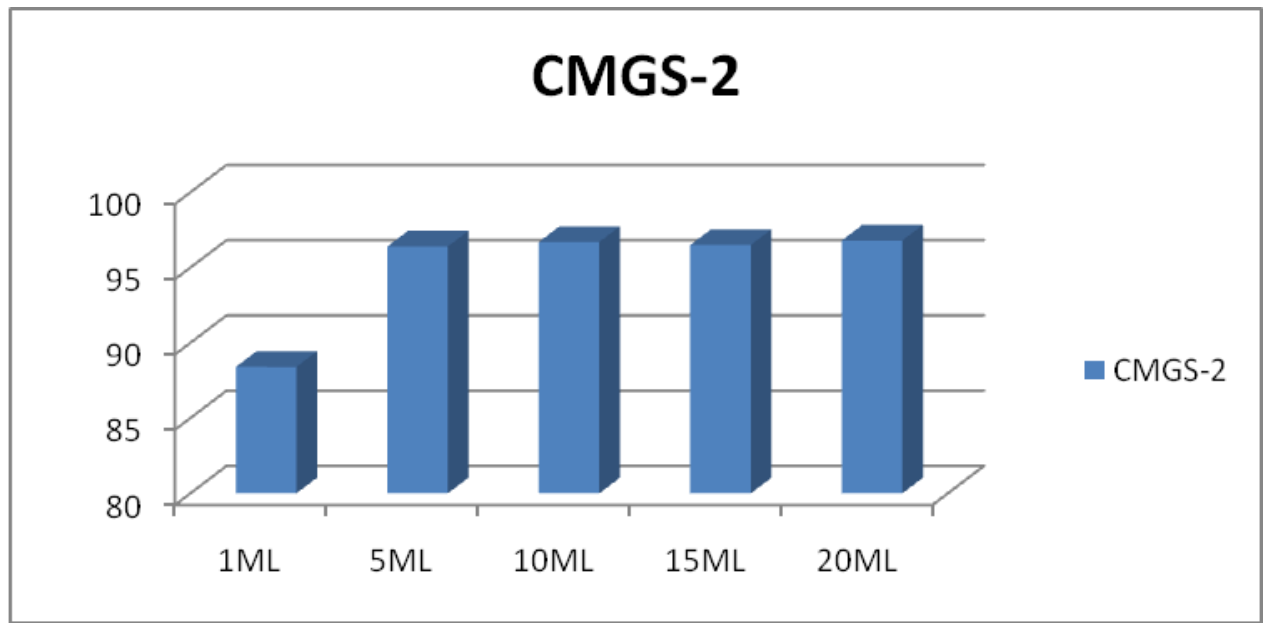

Fig.5 Effect of dye concentration on the decolorisation of Reactive Red-11

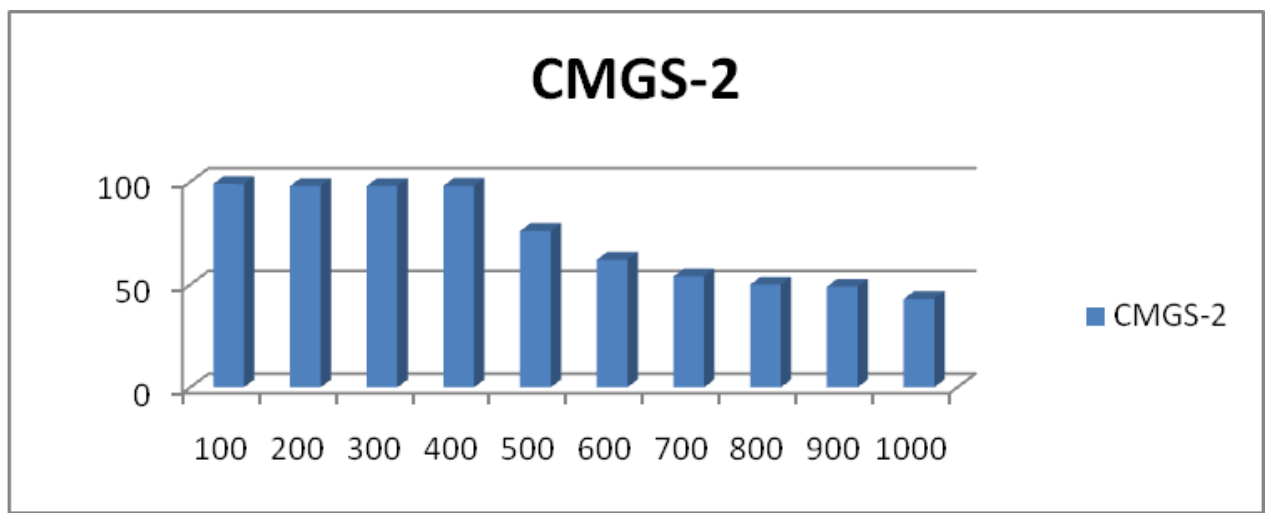


Fig.6 Effect of aeration on the decolorisation of Reactive Red-11

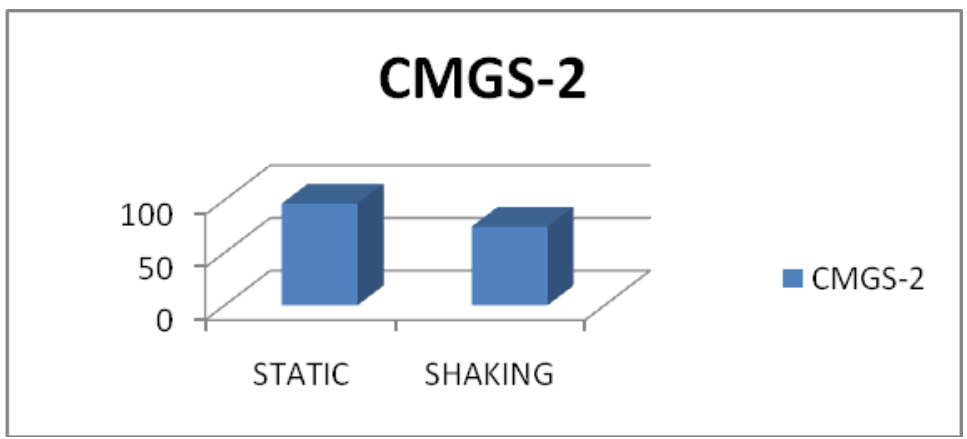

Fig.7 Optimization of yeast concentration on the decolorisation of Reactive Red-11

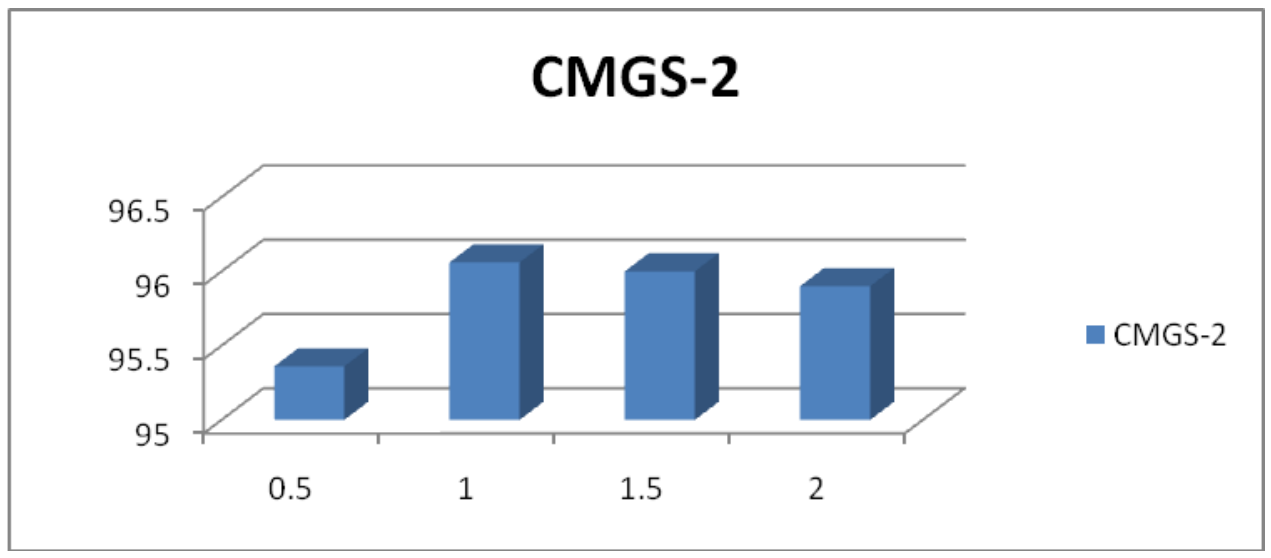

Fig.8 Decolorization of RR-11 by L.boronitolerans at 0hr and $12 \mathrm{hr}$ of incubation

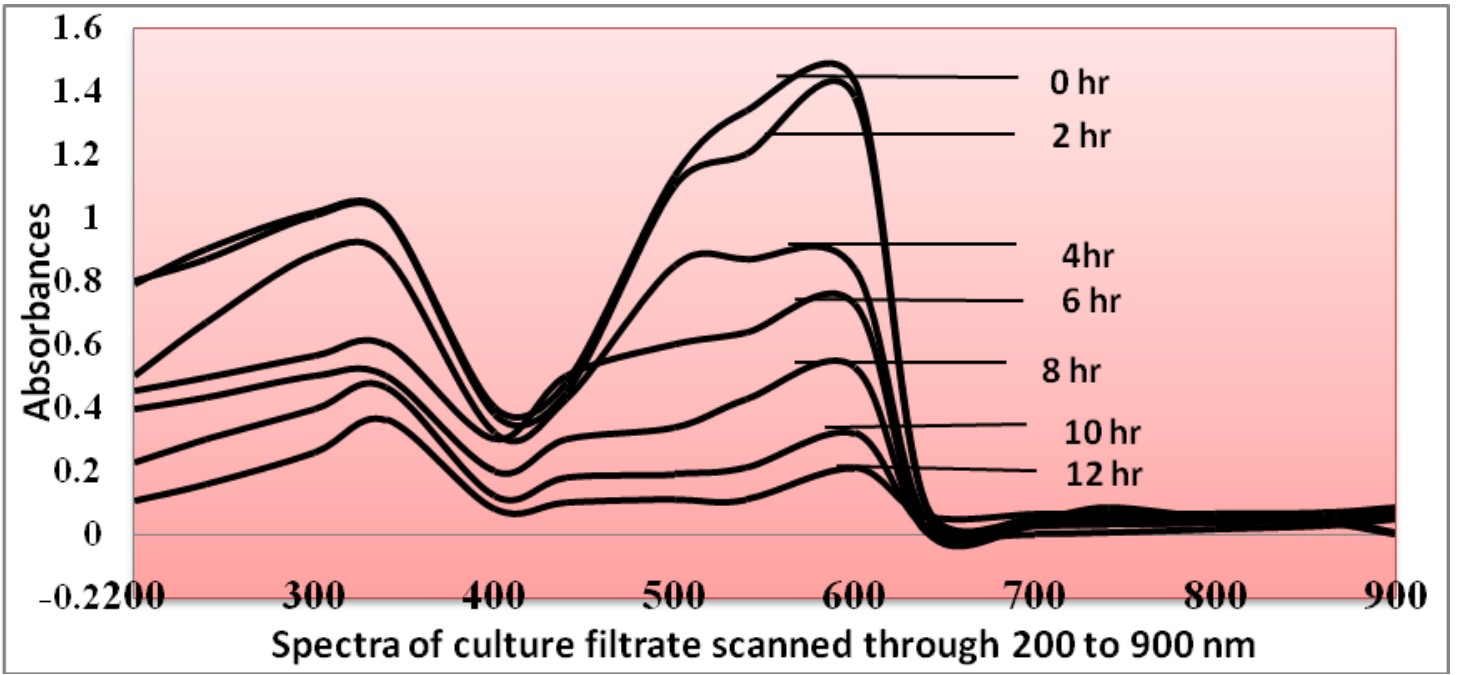

With Increase Concentration Of yeast extract it does not effected on decolorisation Dawkar et al.,(2009) reported decolorisation of the bacillus sp. vus Yeast extract was the best medium for faster decolorization. 


\section{UV-Vis Spectroscopy}

The supernatants of different intervals of incubated DM with RR-11 and CMGS-2 were subjected to scan between 190 to $900 \mathrm{~nm} \mathrm{UV-}$ Vis spectrophotometer results are shown in Fig. 4.24. A single peak at $540 \mathrm{~nm}$ corresponding to $\lambda_{\max }$ of the dye and two intense peaks at $250 \mathrm{~nm}$ and $325 \mathrm{~nm}$ corresponding to phenyl and naphthol rings of RR-11 respectively. With increase in incubation time the peak height at $540 \mathrm{~nm}$ goes on decreased and disappeared after 12 hrs of incubation indicates complete decolorisation of added RR-11 similarly many researchers studied decolorisation using UVSpectrophoometer, Reactive red -195 at 542 $\mathrm{nm}$ by Micrococcus glutamicus by Sahasrabudhe et al., (2014). Metanil yellow at $430 \mathrm{~nm}$ by Lysinibacillus sp. AK2 (Anjeneya et al., 2011).

\section{References}

Anjaneya, O., Yogesh Souche, S., Santoshkumar, M., Karegoudar, T.B. (2011). Decolorization of Sulfonated Azo Dye Metanil Yellow by Newly Isolated Bacterial Strains: Bacillus sp. strain AK1 and Lysinibacillus sp. Strain AK2. J. of Hazard Materials, 190, 351-358.

Bhatt Nikhil., T. Sapna and Kshama, B. (2012). "Biodegradation of reactive red M8B by bacterial consortium". Indian J. Sci. Technol. 5(7):3047-3053.

Bheemaraddi, M., Patil, S., Shivannavar, C.T. and Gaddad, S.M. (2014). Isolation and characterization of Paracoccus sp. GSM2 capable of degrading textile azo dye Reactive Violet 5. Scientific World J. 2014:410704. doi:10.1155/2014/410704.

Chang, J.S., Kuo, T.S., Chao, Y.P., Ho, J.Y. and Lin, P.J. (2000). Azo dye decolorization with a mutant Escherichia coli strain. Biotechnology Letters, 22: 807-812.

C. Brilon, W. Beckmann, M. Hellwig, and H.J. Knackmuss,(1981).Enrichment and isolation of naphthalene sulfonic acidutilizing Pseudomonads. Applied and Environmental Microbiology, vol. 42, no. 1, pp. 39-43.

De Baere, M. Devocht, P. Van Assche and W. Verstraete (1984). Influence of high $\mathrm{NaCl}$ and $\mathrm{HCl}$ salt levels on methanogenic associations. Water Research. 18(5): 543548.

Gahlout, M., Gupte, S., Gupte, A. (2013). Optimization of culture condition for enhanced decolourization and degradation of azo dye Reactive Violet-1 with concomitant production of ligninolytic enzymes by Ganoderma cuperum AG-1". Biotech., 3:143-152.

Gupta, V.K., Gupta, B., Rastogi, A., Agarwal, S. and Nayak, A. (2011). Pesticides Removal from wastewater by Activated Carbon Prepared from Waste Rubber Tire. Water Res., (45): 4047-4055.

Imran, M., Arshad, M., Asghar, N., Asghar M., Crowley, DE. (2014). Potential of Shewanella Sp, Strain IFN4 to Decolorize Azo Dyes under optimal conditions. Int $J$. Agri Boil, 16:578-64.

J. G. Holt, N. R. Krieg, P. H. A. Sneath, J. T. Staley, and S. T. Williams, (1994). Bergey's Manual of Determinative Bacteriology, Williams \& Wilkins,Baltimore, Md, USA, 9th edition.

Jadhav, J.P., Kalyani, D.C., Telke, A.A., Phugare, S.S. and Govindwar, S.P. (2010). Evaluation of the efficacy of a bacterial consortium for the removal of color, reduction of heavy metals, and toxicity from textile dye effluent. Bioresource Technol., 101:165-173.

Jain, K., Shah, V., Chapla, D. and Madamwar, D. (2012). Decolorization and degradation of azo dye reactive Violet $5 R$ by an acclimatized indigenous bacterial mixed cultures-SB4 isolated from anthropogenic dye contaminated soil. $J$. Hazard. Mat., 214: 378-386.

Kalyani, D.C., Telke, A.A., Dhanve, R.S. and Jadhav, J.P. (2009). Ecofriendly biodegradation and detoxification of 
Reactive Red 2 textile dye by newly isolated Pseudomonas sp. SUK1. J. Hazard Mater, 163:735-742.

Kumar Praveen, G.N. and Sumangala K. Bhatt (2011). Fungal Degradation of Azo dyeRed 3BN and Optimization of PhysicoChemical Parameters. Inter $J$ of Environ Sciences, Volume 1, No 6.

Lade, H.S., Waghmode, T.R., Kadam, A.A. and Govindwar, S.P. (2012). Enhanced biodegradation and detoxification of disperse azo dye Rubine GFL and textile industry effluent by defined fungalbacterial consortium. Int Biodeterior Biodegr., 72:94-107.

Lu, K., Zhang, X.L., Zhao, Y.L. and Wu, Z.L. (2010). Removal of color from textile dyeing wastewater by foam separation, Journal of Hazardous Materials, 182(1-3):928-932.

Madhuri M. Sahasrabudhe, Rijuta G. Saratale, Ganesh D. Saratale and Girish R. Pathade (2014). Decolorization and detoxification of sulfonated toxic diazo dye C.I. Direct Red 81 by Enterococcus faecalis YZ 66. J of Environ Health Science and Engineer, 12:151 DOI 10.1186/s40201-014-0151-1.

Manohar, S., Kim, C.K., Karegoudar, T.B. (2001). Enhanced degradation of naphthalene by immobilization of Pseudomonas sp. strain NGK1 in polyurethane foam. Appl. Microbiol. Biotechnol., 55:311-316, DOI 10.1007/s002530000488.

Narsinge, A.P., Hamde, V.S. (2013). Decolorization of textile dye reactive golden yellow 84 by Rhizobium sp. f5. Int. J. Innovative Biotech. Biochem. 1(2): 24-29.

Ogugbue, C.J., Morad, N., Sawidis, T. and Oranusi, N.A. (2012). Decolorization and partial mineralization of a polyazo dye by Bacillus firmus immobilized within tubular polymeric gel. Biotech. 2, 67-78. doi: 10.1007/s13205-011-0035-3.

Panswad, T., Anan, C. (1999). Specific oxygen, ammonia, and nitrate uptake rates of a biological nutrient removal process treating elevated salinity wastewater. Bioresource Technology., 70(3):237-243.

Radhika Birmole, Swamini Patade, Vishwas Sirwaiya, Firdaus Bargirl and Aruna K. (2014). Biodegradation Study of Reactive Blue 172 by dw01 Isolated from lake sediment Shewanella haliotis, Indian J. Sci. Res., 5(1):139-152.

Rajat Pratap Singh, Pradeep Kumar Singh, Ram Lakhan Singh (2014). Bacterial Decolorization of Textile Azo Dye Acid Orange by Staphylococcus hominis RMLRT03. Toxicol Int. 21(2):160166.doi: 10.4103/09716580.139797.

Saratale, R.G., Gandhi, S.S., Purankar, M.V., Kurade, M.B., Govindwar, S.P., Saratale, G.D. (2013). Decolorization and detoxification of sulfonated azo dye CI Remazol Red and textile effluent by isolated Lysinibacillus sp. RGS, Journal of Bioscience and Bioengineering. 115(6):658-667.

Shah, M., Patel, K.A., Nair, S.S. and Darji, A.M. (2013). Microbial degradation of textile dye (Remazol Black B) by Bacillus sp. ETL-2012. J. Bioremed. Biodeg., 4:186.

Tapia-Tussell, R., Perez-Brito, D., RojasHerrera, R., Cortes-Velazauez, A., Rivera-Mu noz, G., Solis-Pereira, S. (2011). New Laccase-Producing Fungi Isolates with Biotechnological Potential in Dye Decolorization. Afr J Biotechnol, 10: 10134-42.

\section{How to cite this article:}

Madhuri R. Basutkar and Channappa T. Shivannavar. 2019. Decolorization Study of Reactive Red11 by using Dye Degrading Bacterial Strain Lysinibacillus boronitolerans CMGS-2. Int.J.Curr.Microbiol.App.Sci. 8(06): 1135-1143. doi: https://doi.org/10.20546/ijcmas.2019.806.140 